\title{
Study on the Prabhavalaya: Aureole of Gods and Goddesses
}

\author{
Prasanna E. Khamitkar ${ }^{1}$
}

\begin{abstract}
Most stand-alone Hindu sculptures of the murtis are supported with a prabhavalaya behind which means a "Luminous circle, an Aureole or a Nimbus " that is the ornate arch, made of stone, wood or metal that stands just behind and above deity images in temples. To analyze the various images of prabhavalaya the author refers to the content extracted from various resources, sculptures of various temples and the most remarkable sculptures from some museums. The author will try to make an effort to classify the visual understanding of the prabhavalayas found in various parts of India that forms as a screen to enhance the importance of various god and goddesses.
\end{abstract}

Key Words: iconography, principle deity, motif, evolution, background, symmetry

\section{Introduction}

Prabha means the halo and valaya is the aura. Hence prabhavalaya or the Luminous circle is an ornate arch, made of stone, wood or metal that stands just behind the principle deity in shrines evolved over the period of time from the concept of a ' halo '. These arches have intricacy of floral patterns. Most important is the depiction of elements in connection with the main deity represented.

The arches behind images pedestals generally bear similar symbols a makhara at the top, vyala or leogryph at the sides, vehicles at the base, ultimately referring to the ultimate, celestial or terrestrial realms respectively. (Smith, An interpretation of the Mukteshwar Temple, 1994)

Kirtimukha as the common element adorns almost all the prabhavalas in the center and so on. The consorts, vehicles, incarnations, attendants or elements connected with that specific form, the sun and the moon etc.. All these constitute a deep study of the elements that are iconographically depicted on the arches behind the main deity. Details of such iconic representations on the prabhavalaya are taken entirely from the traditional texts of Agama and Silpa-sastra, like Brhatsamhita, Manasara, Kasyapa-silpa, Isana-siva-guru-dev paddhati Silparatna, Padma-samhita, Hayasirsa-samhita, Vaikhanasagama and Rupa-mandana. (Daniélou, 1991)

\footnotetext{
${ }^{1}$ Prasanna E. Khamitkar is working as an Assistant Professor at Symbiosis Institute of Design. He is graduated in Applied Arts and has his Masters in Indology. The author specializes in painting Indian Miniatures. Being a performing artist his artistic and spiritual understanding about the iconography of the deities in Hindu Pantheon has served several scholarly interpretations.

Email: kprasanna1o8@gmail.com
} 


\section{Rationale and Significance of the Study}

While representing Surya, Shiva, Vishnu, Ganesha and Durga in form of a sculpture in the earlier period, the sculptor carved these deities in the foreground prominently supported along with an ornate arch or a screen that was represented with the terrestrial, atmospheric and celestial divinities along with. The author makes an effort to show how these backdrop divinities carved in past for sculptures could have been the origin for the representation of the prabhavalayas.

\section{Aims and Objectives}

The proposed research aims to bring out the significance of the 'prabhavalayas' of the gods and goddesses in the purana texts.

- To represent a few examples of deities that had an ornate screen evolved to form the prabhavalaya over the period of time.

- To categorize the iconographical details of the formation of prabhavalaya bringing the relationship of art and philosophy.

- To promote the richness and authenticity of Indian Heritage by studying the design factors involved in the iconic representations of the motifs used in the prabhavalayas.

\section{Characteristics of the Prabhavalaya}

- The prabhavalaya is primarily that forms the background screen of a deity.

- Contains images that are connected with the main deity and enables to give traces of legends thereby.

- The images associated with the main deity on the prabhavalaya are normally smaller in size in proportion to the main deity that forms the subject matter. This makes the principle deity look dominant.

- The elements are normally presented in the manner that can enhance the significance of the principle deity.

- Carved in ornate style the leo-graphs along with the floral representations add to the decorative look.

The formation of the deities and the symbols are used to represent universal principles. The apparent origins of the various gods like the terrestrial, atmospheric, celestial etc. and the histories of their names should not be taken as an indisputable evidence of an evolution in religious ideas.

The outlook of modern people is analytical. They tend to differentiate and isolate the various elements, religious, social, philosophical, which have combined to give its present form to the Hindu pantheon. The Hindu approach, on the other hand, being basically cosmological, tries to find an equivalent, a sort of legal pattern in its own tradition, for any new idea or system which it wants to understand or assimilate. (Daniélou, 1991)

An iconographic study complete and absolute is the nature of the divinities of the cosmic forces represented in their spiritual manifestations with attributes that designate their extensive energies on the arches or prabhavalayas they are depicted against the gods to inherit to transcend upon the mortals to lead them to immortality.

The importance of identifying motifs is central to iconographical interpretation. Hence an intricate and a vast scope to investigate these designs carved in various time periods in the various 
dynasties of those times they belonged to. An in-depth study of such prabhavalayas that contain deeper understanding from the texts is what an interesting fact that could contribute to the field of Indology.

Prabhavalaya have been equally important as the deity itself and it has seen that there has been no compromise in carving the intricate details to support as the backdrop of the deity in the foreground. The depth of the carving of such prabhavalaya depended on the relief of the sculpture been carved. To bring out a deeper understanding of the icons connected along with the deity represented thereby on these ornamented arches, deals as an important section in the iconography of the brahmanical deities. The study of iconography indeed enables one to understand and bring a connection of the elements represented on these arches that portray the extensive energies of the personality carved as the main subject in the center. Presentation of motifs, as well as the production and interpretation of images, stories and allegories give meaning and identity even to the formal arrangements and technical procedures employed. (Meijer, 2011)

Interesting facts could be presented in this connection to bring the higher understanding of the cosmic forces that manifested through the hands of the artisans upon such arches or prabhavalayas and helped the worshipper to connect with the cosmic energy that undoubtedly through the process of one's worship, meditation and contemplation transcended to the world of the divine.

\section{The Genesis}

Several gods and goddesses coming under the Hindu pantheon seem to have been carved with iconographical details that depicted the entire cosmic realm of that personality before $13^{\text {th }}$ century AD. Artisans seem to have got a wider scope of depicting these representations on the backdrop of sculptures that carried these divinities as their own attributes.

The author selects a few amongst them like Shiva, Durga, Surya, Ganesha and Vishnu to show how the sculptures carved in past had several details and how in the later period they evolved with the representations of prabhavalayas after the $13^{\text {th }}$ century.

\section{Shiva}

The below sculpture portrays a very unusual image from the Pala Dynasty of Lord Shiva in form of Mrityunjay, who is said to have victory over Yama the presiding personality for Death. Shiva is seen sitting in dhyana, a meditative posture in padmasana, a squat position of legs comfortably on a lotus pedestal on which appear a kinnari and kinnara holding musical instruments. Kinnari and kinnara are minor demigod musicians half-human and half-bird and are often seen appearing on Pala-period thrones. (Thakur, 1997) The throne is placed against a lush background of flowering scrolls. Depicted having six arms the image of Shiva is supported with a prominent ornate screen behind him with interesting attributes. The two female figures are holding the fly whisks on either side along with the consorts seen sitting on a horizontal pedestal supported by makaras. Nandi is seen represented on the pedestal below. Four flying celestials, two of whom have consorts, cavort on either side of the kirtimukha, or face of glory, at the top of the arch. The richly ornately carved surface of the Stella and its pointed top are a typical of the twelfth century. 


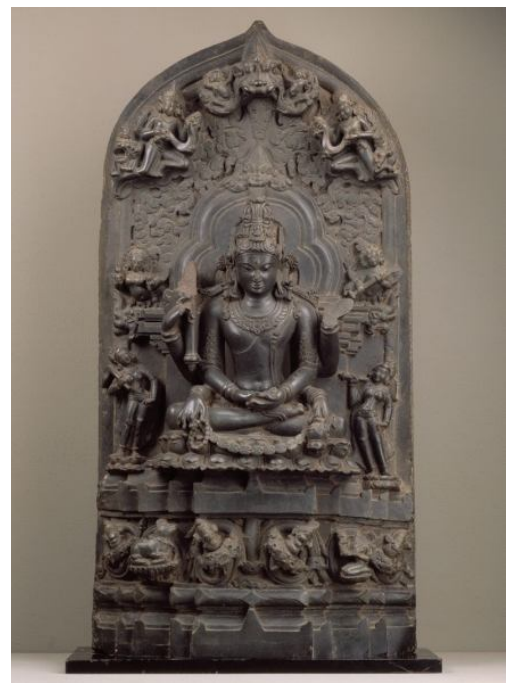

Figure no 1: Shiva as Mrityunjaya, Conqueror of Death: Pala Dynasty

A backdrop screen with such details actually elevates the principle deity from its background making it look very significant.

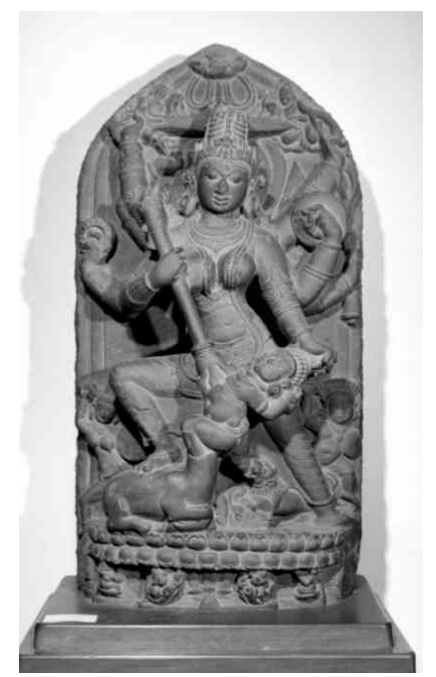

Figure no 2: Durga, late $10^{\text {th }}-$ early $1^{\text {th }}$; Ashutosh Museum, Calcutta

\section{Durga}

Unlike any other form this form of Durga called Mahishasurmardini in stone has a plain screen as a backdrop contradicting a few details on top like the vidyadharas offering garlands. The floral arch that begins with on the nimbus that carves out a niche behind the deity meets in point on the center above to depict a kirtimukha. 


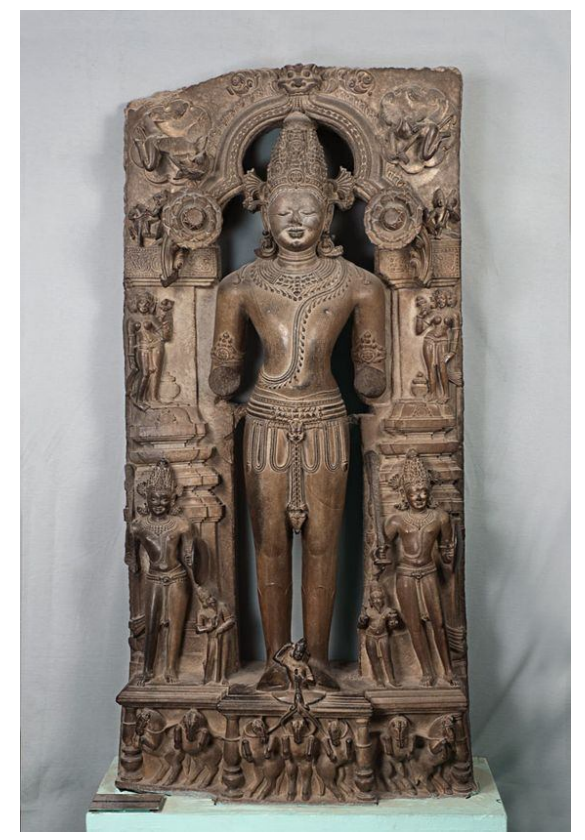

Figure no 3: Surya of Konark 13th century AD, Eastern Ganga Dynasty

\section{Surya}

This sculpture carved minutely with a wide range of subordinate imagery is one of the finest from the Sun temple, Konark, in Orissa. The halo or the nimbus of this deity seems to have been kept open in form of a negative space right behind the head of the deity. Primarily known as the source of light, warmth and life, the image of Surya represented time and cosmic dynamics. On top of the backdrop screen one can see 'Maladharas' showering flowers, vina-playing Gandharva along with an equestrian messenger. On the right and left of the prabhavalaya's upper part, flowerbunches carrying female attendants and the male attendants accompanied with sages is seen to form the most striking feature. The seven horses gallop at the base controlled by Aruna the charioteer driving Surya's cart.

Two female figures attending on him as his consorts on either sides of his torso are Chhaya and Suvarchasa, and the two males are Danda and Pingala, his principal attendants. Pingala begins appearing in sculptures as an independent theme since at least the 4th century AD. (Sahu, 2011)

Once adorned the sanctum of Konark Sun Temple at Odisha this sculpture for safety has now been transferred to National Museum New Delhi for security.

\section{Artistic Approach}

The negative space left in form of an aureole could be termed as the prabhavalaya behind the head of the deity and is quite significant as it gives an elevation to the personality of Surya standing in samabhanga position. This also supports the understanding of an open space in the Gestalt principle that we imply a meaning with its connected elements. It's a space with an implied meaning of an invisible halo. (Bag, 2012) This space naturally separates the principle deity 
from all other attributes around it giving it an image carved in 360 degrees unlike the other ones who have their backs flattened along with the surface of the backdrop.

This beautiful symmetric arch forms an interesting center at the top of the crown merging in one single point that is adorned with the kirtimukha very intricately carved. The geometric vertical lines that form the indication of pillars to blend with the ratha style of architecture of the temple are very evident.

Negative space as a very important aspect of design, symmetry, decorative motifs, and softness in chiseling are a few design vocabularies the artifact allows understanding the image to appreciate the creative mind behind its formation.

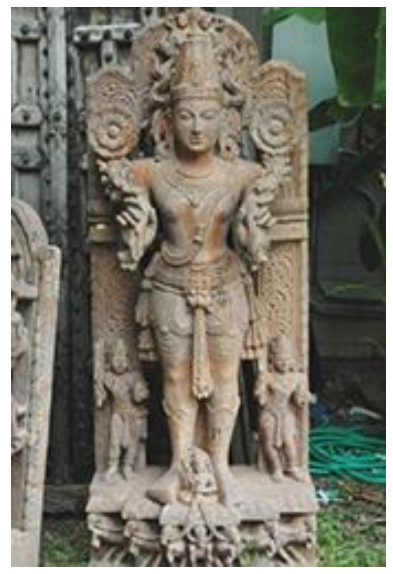

Figure no 4: Recent iconographical details of Sun God

The recent Sculptures of Surya do not seem too much go deeper with figurines around that depicted the terrestrial, atmospheric and the celestial world around the deity. Indeed the orthodox schools of sculptors cease to exist who once followed the agamic instructions in the preparation of the image. (Rao, 1985)

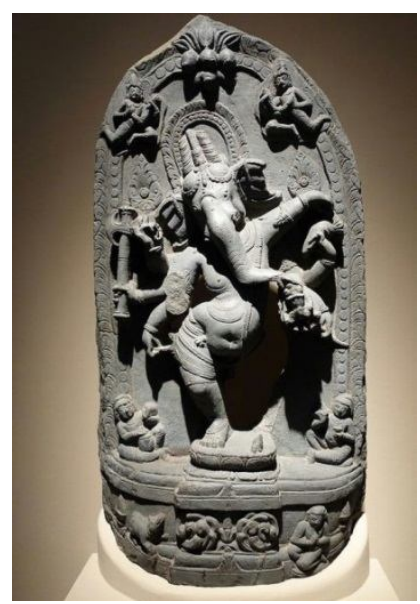

Figure no 5: Dancing Ganesha, Pala Period late ntth century: Chazen Museum of Art

\section{Ganesha}

The main deity of Ganesha has the images on the backdrop screen kept in low relief carving simple geometric motifs culminating in floral patterns that meet the kirtimukha in the center above with the single vidyadharas (celestial wizard) holding garlands on either side. (White, 1996) 
Musicians and the mouse are quite evident below along with another yaksha offering his respects to the deity above.

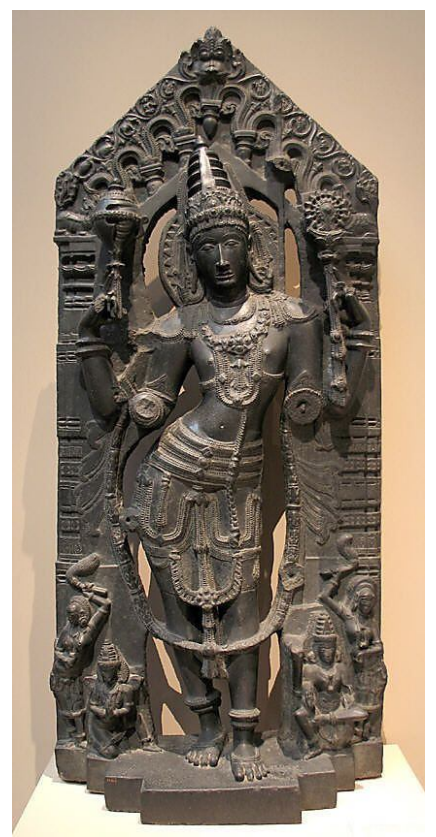

Figure no 6: Vishnu with Lakshmi, Garuda, \& attendants, Andhra Pradesh, India.

Kakatiya period: $12^{\text {th }}-13^{\text {th }}$ century

\section{Vishnu}

A very unusual standing position of Vishnu( fig: 06) in tribhanga or three bents in the body supported with a backdrop with the most prominent elements associated with him. The background has an opening that keeps the image complete in all 36o degrees and supports the head with a nimbus intricately carved in form to form the halo. Triangular backdrop screen that is depicted has prominently kirtimukha on top right in the center and his consort Lakshmi represented with her four hands is depicted on his left sitting in sukhasana. Garuda the vehicle of Vishnu can be seen on the right of the deity in the Anjali mudra. (Daniélou, 1991) Fly whisks bearers as female attendants are flanked on either side. Pillar representations with low relief can be seen prominently on the left and the right of the deity.

\section{Evolution of the concept of Prabhavalaya}

In the earlier period as seen in the above sculptures of various gods and goddesses one gets to see the luminous circle or the nimbus in form of a circle forming a negative space and surrounding this imaginary halo was carved the entire cosmic world of the deity. The terrestrial, the atmospheric and celestial minor gods and goddesses were all carved around this principle deity. Eventually it can be observed that when the devotional or bhakti movements influenced the society the artisans started giving importance to the prime deity according to the requirement of the worshipper or the bhakta. An image of the ishta or one's personal deity who represents a certain cosmic force was kept in front of the worshipper with attributes added to the image upon which the worshipper desires to concentrate his thoughts. (Rao, 1985) 
Whatever ishta or personal form of a specific deity the worshipper selected, Sringar became one of the important aspect in the deity worship when one offers various paraphernalia to the personality. In the purport of a shloka from Srimad Bhagvatam (2.3.22) Bhaktivedanta Swami Srila Prabhupad mentions the importance of deity worship by presenting a few lines written by a Vaishnav poet Srila Vishwanath Chakravarty Thakur.

\section{śrī-vigrahārādhana-nitya-nānā \\ śrrngāra-tan-mandira-mārjanādau}

Sri -vigraha is the archa, or suitable worshippable form of the Lord, and the disciple should be engaged in worshiping the Deity regularly by sringar by proper decoration and dressing, as also by mandir-marjana the matter of cleansing the temple. (His Divine Grace A.C.Bhaktivedanta Swami Srila Prabhupada, 1972)

However the negative space of the earlier aureole in stone sculptures seems to have become the focus got converted into positive space of the composition and the concept of nimbus or the luminous circle became more established in form of a prabhavalaya that evolved with various attributes that would give importance to the deity dominating its presence by offering a throne like detachable structure with all the embellishments that formed the background to meet the requirements of sringar in the devotional process. The worshipper exalts the deity by adding attributes of the highest standard that will take the deity to the throne of the Almighty. (Edward Moor, 1810)

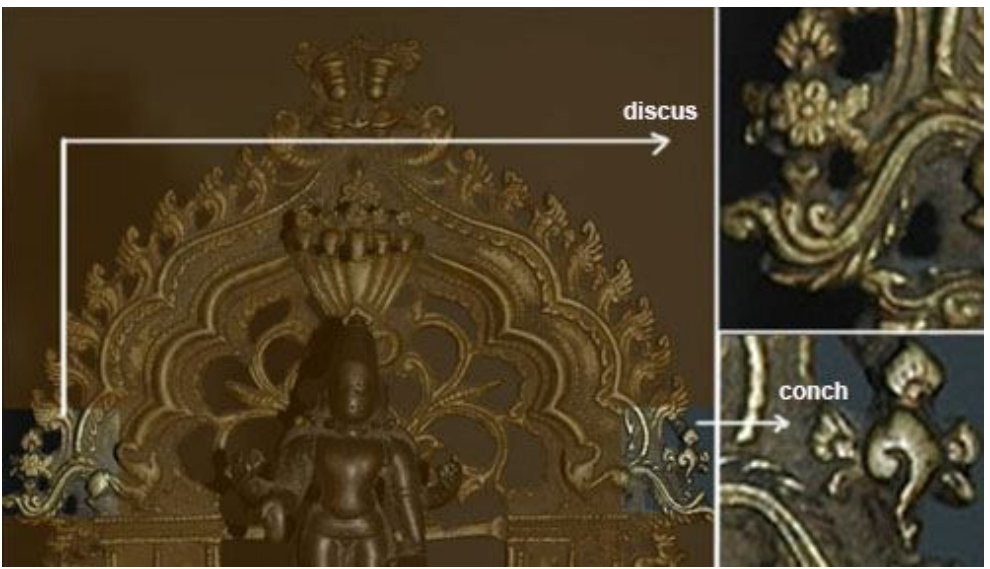

Figure no 7a: Conch and Discus on a prabhavalaya for Vishnu deity

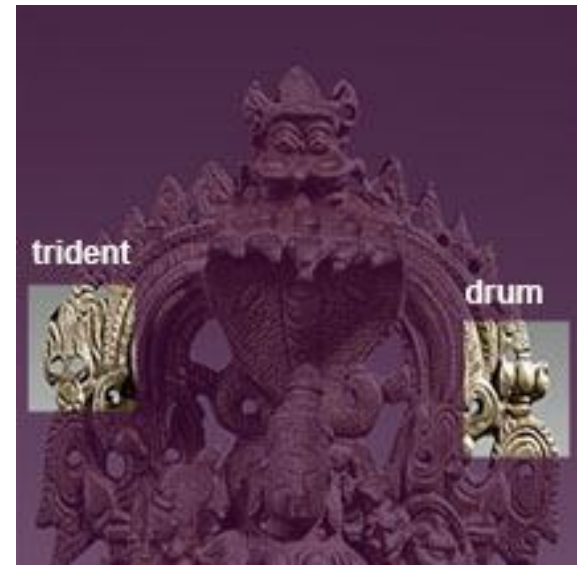

Figure no 7 b: Trident and Drum on a prabhavalaya for Durga

Thus the flat background or an arch supported the deity with elements connected with the principle deity to enhance the deity's presence. For example the prabhavalaya of Vishnu (fig: 7a) could be seen with conch and discus on its either sides that symbolize the presence of Vaishnav cult. Likewise trident and drum are depicted on the prabhavalaya for Durga. (fig : $7 \mathrm{~b}$ )

Thus the design of a prabhavalaya evolved to the present on the basis of the sculptures from past centuries and got established in form of a pedestal added with various attributes suitable to the iconography of the deity.

\section{The structure of the Prabhavalaya}

A prabhavalaya primarily would constitute of two parts mainly the base or the pedestal and the screen supported behind for the deity. The screen behind has two protrusions that get inserted in 
the base behind where it has two cavities that coincide with the screen protrusions. There's a specific arrangement made even for the deity to get fixed on the base below. So the sequence goes that the deity is first inserted on the base and then the screen is put behind.( fig : 8) The other embellishments on the screen behind are added after this.

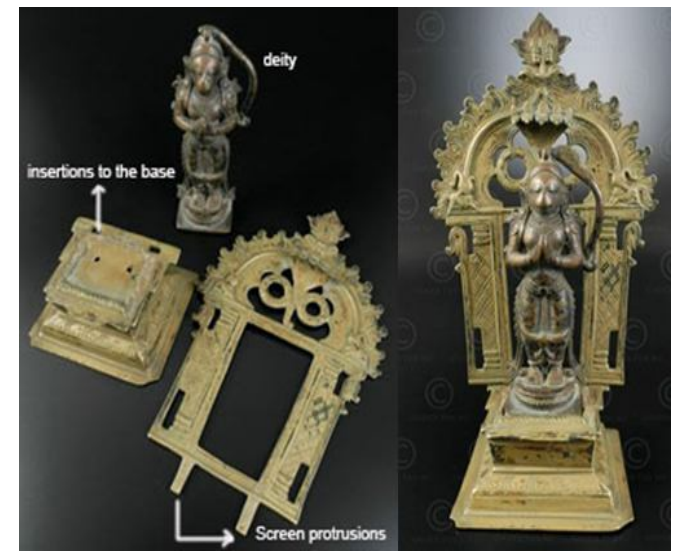

Figure no 8: Dismantled parts of a prabhavalaya

Prabhavalaya could be seen forming a single arch, a twin arch or the ones forming the three divisions. In case of a single deity established it would bear the single arch as shown in fig: 9

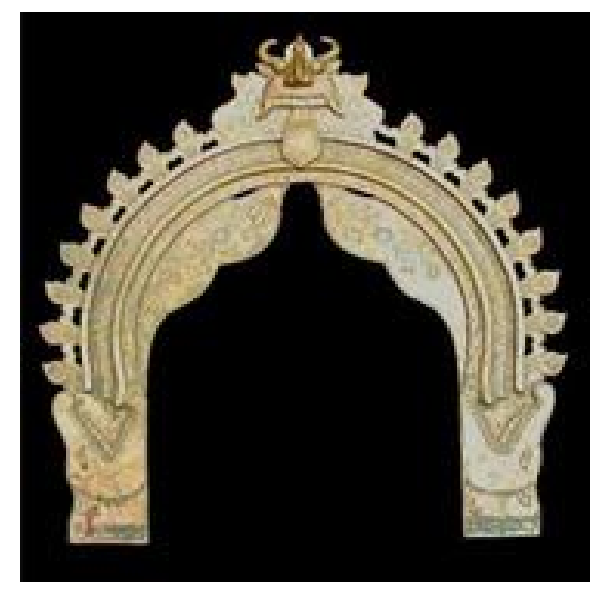

Figure no 9: Prabhavalaya for a single deity

In case of a couple like the Umasahita Sadashiva it may have two arches. Fig: 10

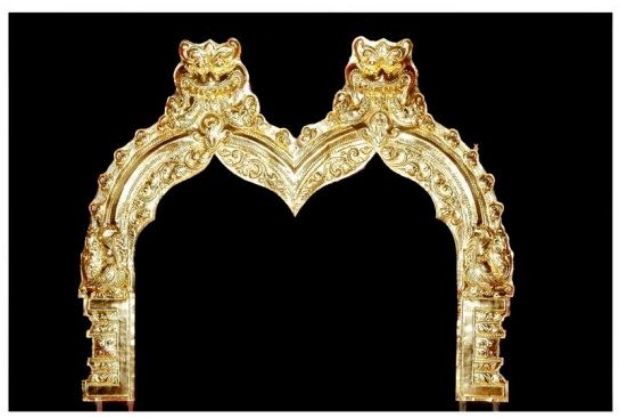

Figure no 1o: Prabhavalaya for a couple deities 
And three arches combined in the prabhavalaya for deities that stand in a triplet like Kartikeya (fig.:11) accompanied with his consorts Devsena and Valli. (Sivananda, 1996) The primary structure yet remains stable and same.

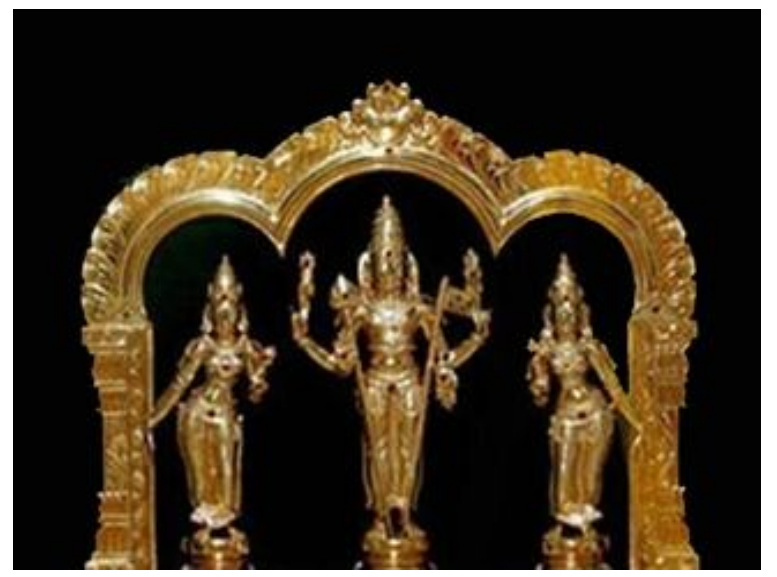

Figure no 11: Prabhavalaya for three deities

Various motifs got added to this prabhavalaya like the kirtimukha, makara, vyala, ayudha, pataka or the flag, the abdagiri and the chattravali as shown in the fig: 12

The size of any prabhavalaya depends on the size of the deity.

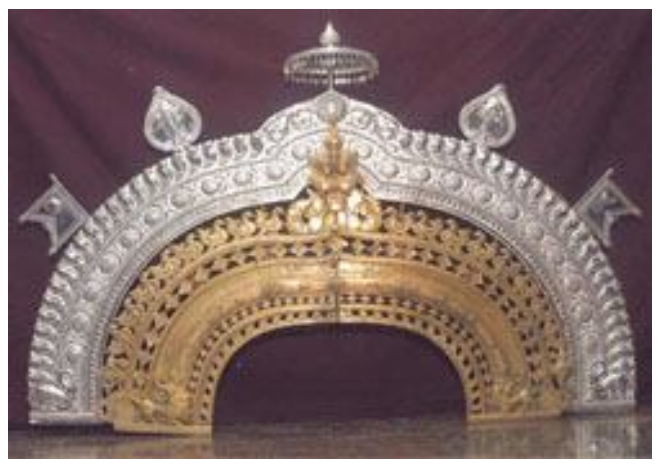

Figure no 12: Prabhavalaya with other embellishments

\section{Symmetry}

Symmetry being the important aspect from an artistic point of view the image is repeated as motifs on eithers sides to give an aesthetically complete look to the entire structure of prabhavalaya. (Kim Williams, 1998)

This enhances the look of the entire structure to bring the principle deity forcefully to the worshipper to make the deity as an object of contemplation.

The central axis of the prabhavalaya is controlled by the motif of a kirtimukha that acts as an axis to create reflections of the elements like makaras, vyalas, and the ayudhas mirrored on both sides. 


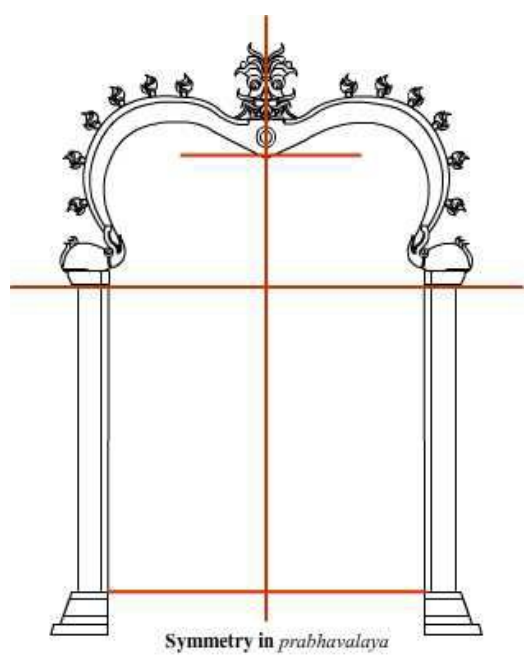

Figure no 13 : Symmetry

Symmetry enhances the visual Interest of the observer.

As nicely framed up statement by M.A. Hann and B.G. Thomas, "Motifs are the building blocks from which patterns are produced. They may be either symmetrical or asymmetrical. A symmetrical motif is comprised of two or more parts, of identical size, shape and content." (Thomas, Beyond the bilateral - Symmetry in two-dimensional design, 2007) Thus, Symmetry brings repetition of motifs on the prabhavalaya to form a symmetrical balance.

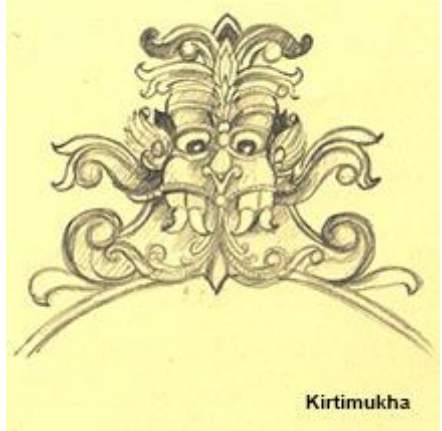

Figure no 14 : Kirtimukha

\section{Kirtimukha:}

Kirtimukha is one of the very important elements of a Prabhavalaya. It has been a very important element of the makharas or prabhaval. (Patil, 2014) Kirti means the glory and mukha means the face. The existence of kirtimukha on the prabhavalaya has its roots in skanda purana that mentions about the demon who received the benediction from Shiva to be adorned on the arches.

However kirtimukha is seen on the entrance of a temple or in the central portions of the prabhavalaya surrounded by creepers or flowers, gaping mouth with a tongue rolling down and thus adorned with the ayudhas or elements of the deity it is connected with. (Stella Kramrisch, 1976) This face of glory became an auspicious motif in Hindu, Jain and Buddhist shrines to represent as a guardian deity above all abodes of the divinities. The scholars say that he is the wisdom personified and the glory that results from wisdom and Self Realization. (Patil, 2014) 
In fact a prabhavalaya without a kirtimukha looks incomplete. Various cultures have adopted this specific form and applied in their traditional patterns to add glory.

\section{Other elements in the Prabhavalaya}

Several other forms along with kirtimukha like the makara, vyala, dhwaja the flag, abdagiri, a cobra hood and the ayudhas like the conch, discus, drum or trident eventually contributed their importance in the presence of the prabhavalaya for the deity they were meant for.

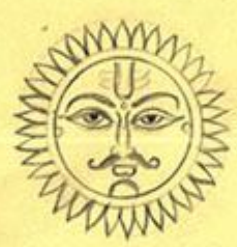

Surya

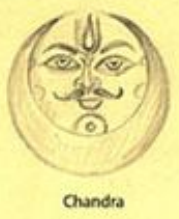

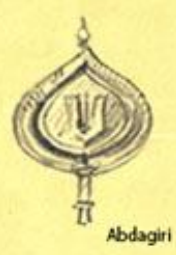
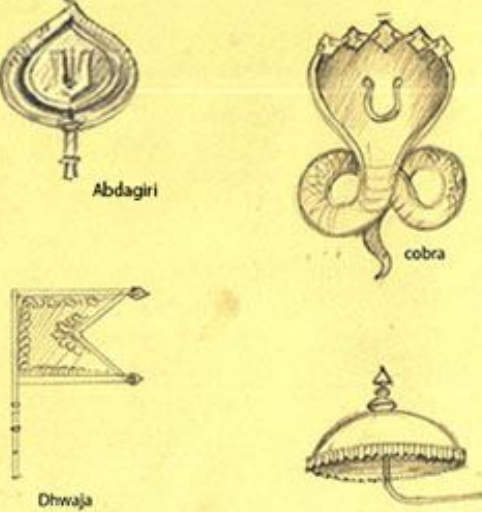

Figure no 15: Elements of a prabhavalaya

The elements like dhwaja, abdagiri and chatravali are inserted in a socket behind the prabhavalaya that adds a royal look to one's personal deity. (Ramchandra Kaulacara, 1966)

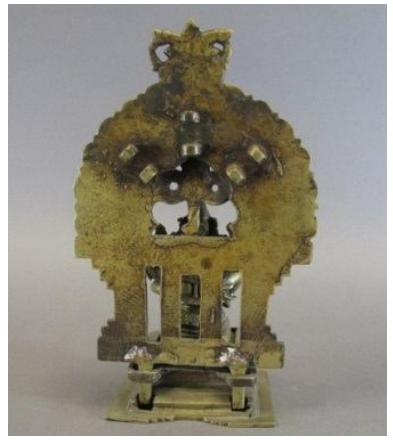

Figure no 16: Background sockets

The above image ( fig: 16) shows an arrangement of sockets made for the elements to be inserted behind the prabhavalaya. In Hinduism, the cosmological theory along with its symbolism is conceived as an expression of a reality, as a search for the particular points where different order of things may become apparent.

The concept of the Hindu pantheon and its iconographical theory are based on the belief that such affinities exist. Thus an aspect of divinity is to be represented and supported with the ornate arches like the prabhavalaya and worshipped in forms which are extremely diverse. The 
various forms have been used indifferently as a support depicted on the intricate ornate arches, the prabhavalaya which become an instrument of ritual or meditation to reach the principle of which they are the images, the manifest aspects.

\section{Detachable Prabhavalaya of Uma Maheshwar}

An interesting and a detachable prabhavalaya from Karnataka dated early $19^{\text {th }}$ century depicts Uma Maheshvara together seated on the bull Nandi, vehicle of Lord Shiva . (fig:17) This design is made of four individual parts: prabhavalaya (back plate), bhadrapeetham (base) and the deities of Nandi and Uma Maheshvara.

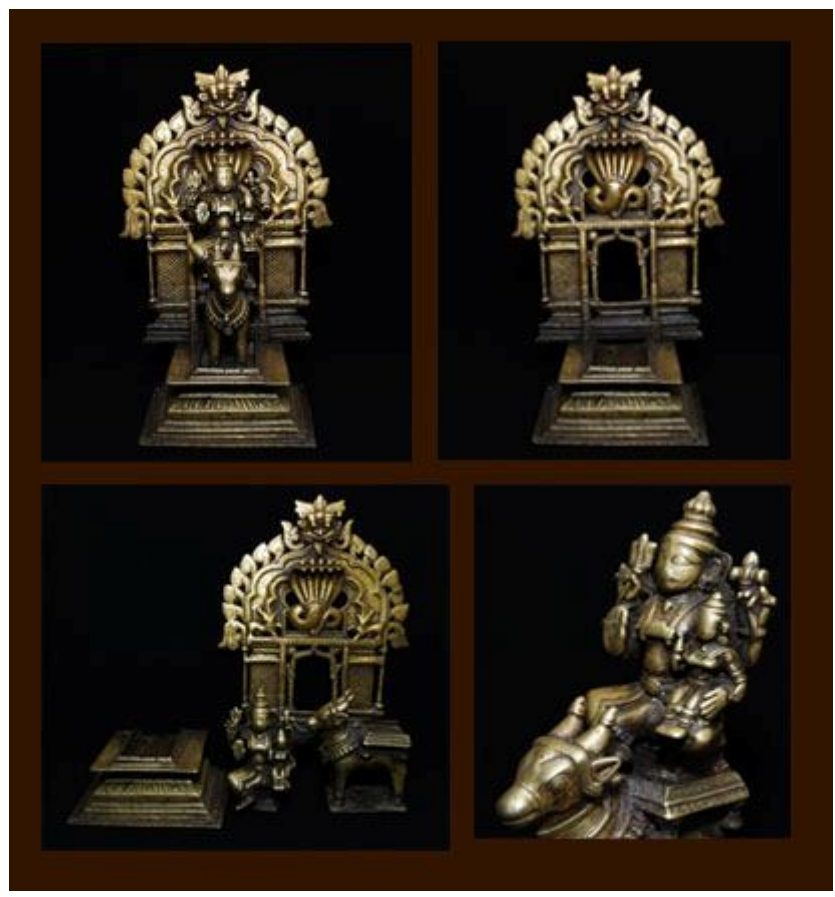

Figure no 17: Prabhavalaya designed for Uma Maheshwar

\section{The Prabhavalaya of Durga}

The images below from 12th century depict Goddess Durga, slaying the Buffalo Demon Mahishasura. Depicted in the act of conquering the buffalo demon Mahishasura the image serves for an altar shrine complete with a lustration basin. The anthropomorphic form of the demon is very evident. The lotus-petal nimbus framing the goddess's head is a motif specific to imagery of the Chamba Valley region. As mentioned earlier the nimbus or the prabhavalaya plays an important role in supporting the back rest of the brass figurine. Various elements like the yakshas, elephants, yali and floral motifs adorn the prabhavalaya with its intricate details. Kirtimukha seems absent in this design but a floral luminous circle with beautifully shaped eight petal lotus forms a striking feature of the prabhavalaya. 


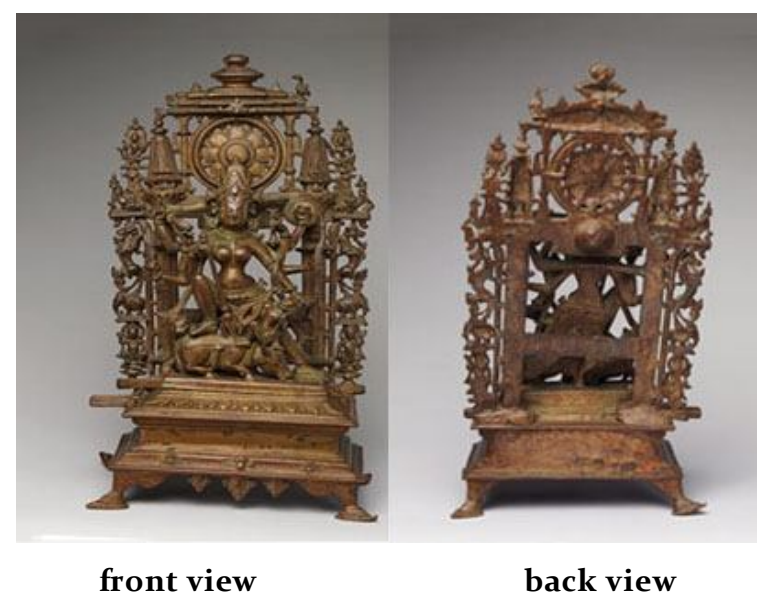

Figure no 18: Prabhavalaya for Durga

The backdrop screen is seen fixed in the base below with two insertions that holds the screen straight behind the deity. No details or figurines are ever seen carved on this portion behind unseen to the worshipper.

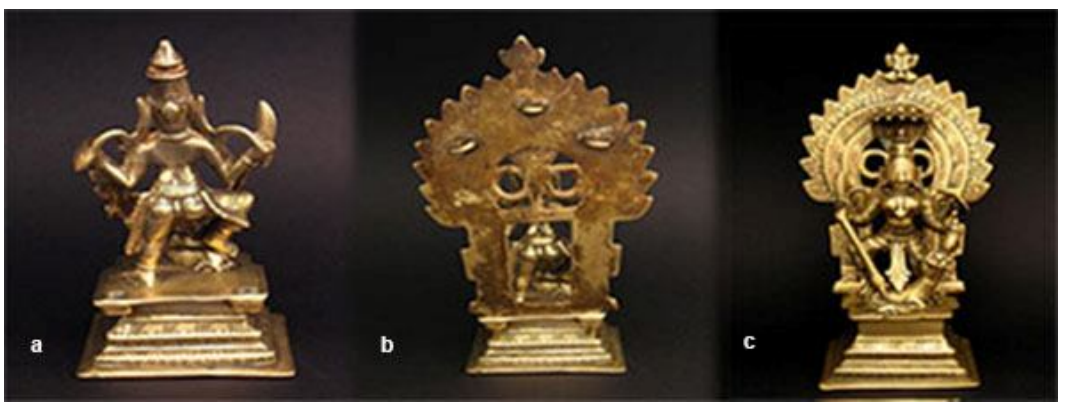
a) Back portion of the deity
b) back portion of the prabhavalaya
c) assembled

Figure no 19: Prabhavalaya for Durga as Mahishasurmardini $18^{\text {th }} / 19^{\text {th }}$ century

Another example of the prabhavalaya is the one made for the deity of Mahisharsurmardini, a form of Parvati. The deities made in brass have a very specific form of prabhavalaya like the one portrayed in the image above. The four handed form of Durga slaying the demon Mahishasura is been depicted with four arms holding various attributes. An extravagant detachable prabhavalaya is engraved with swirls that represent the radiating energy of the goddess. These swirls was carved in various shapes suitable to the deity the arch was made for. A five hooded cobra is seen that rears over her head forming a canopy a very common feature in the brass prabhavalayas.

The various motifs a prabhavalaya bears gave stability and firmness to the deity placed intact in the altar. A base and a backdrop support are the most important features of a prabhavalaya. From the evolution of sculptures made in the past centuries with divinities represented on its backdrop screen gradually diminished the details of the terrestrial, atmospheric and celestial beings keeping in prominence the most important elements icons connected with the form. 
A few examples of the Prabhavalayas:

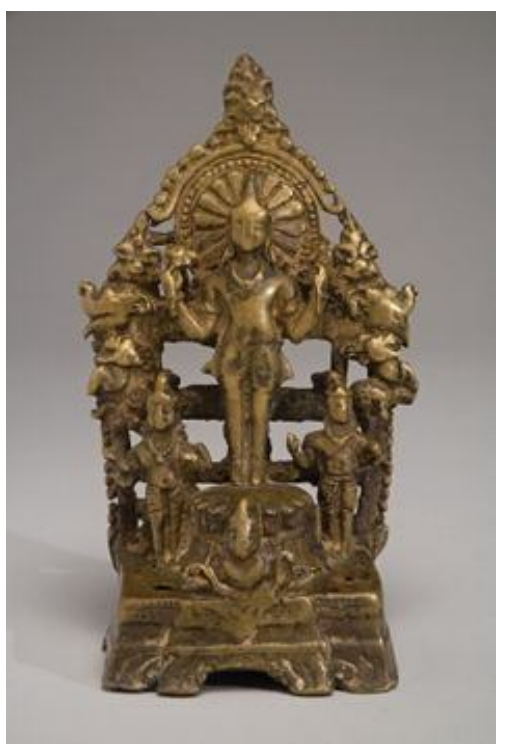

Figure no 2o: Prabhavalaya of Sun-God

\section{Prabhavalaya for Sun God, $1^{\text {th }}$ cen.}

The prabhavalaya of Sun God here seems to have attributed with his attendants danda and pingala on either sides. The backdrop is supported with a halo in form of a circle showing the rays of the Sun. Vyala and makaras are prominently seen. Seven horses below with Aruna the charioteer are seen.

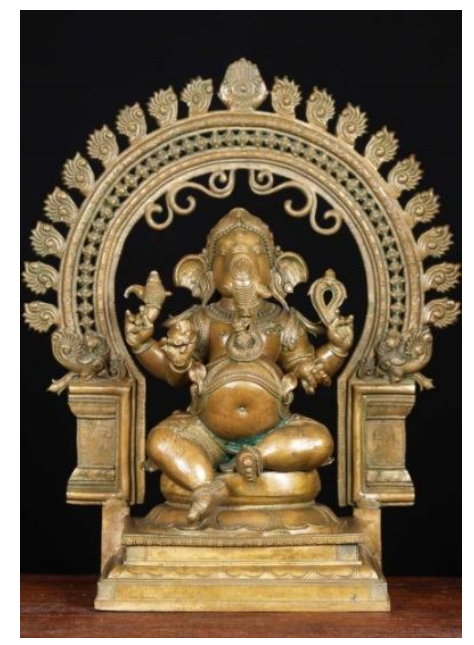

Figure no 21: Ganesha in a prabhavalaya

A very articulate form of prabhavalaya with swirls in form flames representing the cosmic nature of Ganesha. (Fig: 21) The location of makaras has been replaced by peacocks .Two makaras facing the opposite directions are placed in the center of the arch above. 


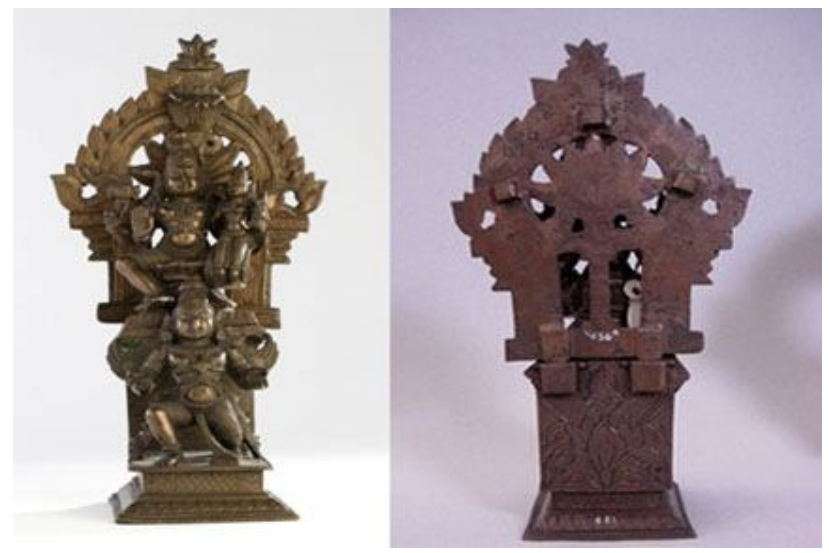

Figure no 22: Vishnu in a prabhavalaya (front and back view)

A complex prabhavalaya in a front and a back view, depictsVishnu (fig: 22) with his consort Lakshmi sitting on his lap dated $19^{\text {th }}$ century.

Vishnu is seen seating in lalitasana with Sri sitting on his left lap. This form is called as the Lakshmi- Narayana.The divine couple is supported by his vehicle Garuda with his hands stretched forward in awe and reverence to his master. The figure is shown surrounded by a prabhavalaya with radiating swirls with a naga canopy upon the head of the deity. Kirtimukha adorns the structure in the center above. This exclusive prabhavalaya is an exemplary piece.

\section{Conclusion}

The most important aspect in the worship is to add glory and importance to the personal deity chosen to seek connection with the almighty. The prabhavalaya enables to enhance the importance of the deity chosen by offering him or her throne to reside.

The evolution of the prabhavalaya seems to somewhere have its roots in the sculptures carved in previous centuries as explained above. Evolved to form a firm structure designed with a sole purpose for worshipping the deity, the prabhavalaya makes the form to the worshipper look complete with all its attributes. An attribute added to the deity enhances and enables the worshipper to develop spiritual insight and enjoy the peace and bliss.

However the concept of prabhavalaya in real sense travels the journey from art to the concept of design especially doing justice to the ergonomics of the structure of the prabhavalaya.

\section{Bibliography:}

Bag, J. (2012). The architectural spaces and Their psychological impacts. National Conference on Cognitive Research on Human Perception of Built Environment for Health and Wellbeing, (pp. 5-12). Vishakhapatnam.

Daniélou, A. (1991). The Myths and Gods of India: The Classic Work on Hindu Polytheism . Rochestor, Vermont: Inner Traditions International.

Edward Moor, F. (1810). The Hindu Pantheon.

His Divine Grace A.C.Bhaktivedanta Swami Srila Prabhupada, F. A. (1972). Srimad Bhagvatam. Los Angeles: The Bhaktivedanta Book Trust . 
51 | Study on the Prabhavalaya: Aureole of Gods and Goddesses

Kim Williams, A. (1998, December 32). Symmetry in Architecture.

Meijer, V. (2011, 12). Iconography, iconology and style analysis. p. 15.

Patil, D. V. (2014, March 3 ). Kirtimukha - The Face Of Glory. Heritage.

Ramchandra Kaulacara, t. b. (1966). Silpa Prakasa Medieval Orissan Sanskrit Text on Temple Architecture. Leiden: E.J. Brill.

Rao, T. (1985). Elements of Hindu Iconography. Delhi: Motilal Banarsidass.

Sahu, R. K. (2011). Iconography of Surya in the Temple Art of Odisha. orissa.

Sivananda, S. S. (1996). Lord Shanmukha and His Worship. Shivanandanagar: The Divine Life Society.

Smith, W. (1994). An interpretation of the Mukteshwar Temple. Delhi : Motilal Banrsi das Publishers Private Limited.

Stella Kramrisch, R. B. (1976). The Hindu Temple, Volume 2. Delhi : Motilal Banarsidass .

Thakur, M. R. (1997). Myths, Rituals and Beliefs in Himachal Pradhesh. New Delhi, India: M.L.Gidwani, Indus Publishing Company.

Thomas, M. H. (2007). Beyond the bilateral - Symmetry in two-dimensional design. International Association of Societies, p. 15.

White, D. G. (1996). The Alchemical Body: Siddha Traditions in Medieval India. Chicago and London, United States of America: The University of Chicago.

\section{Images References :}

Figure no $1:$ http://www.metmuseum.org/toah/works-of-art/1991.421/ viewed on 28 -04-2016

Figure no $2:$ https://in.pinterest.com/pin/385268943101539146 viewed on 27-o4-2016

Figure no 3: http://www.nationalmuseumindia.gov.in/images/products/Surya.jpg viewed on 24-06-2016 Figure no 4 : https://in.pinterest.com/pin/470063279837693229/ viewed on 21- 4-2016

Figure no 5 : https://in.pinterest.com/pin/385268943101150669/ viewed on 27-04-2016

Figure no 6 : https://in.pinterest.com/pin/76209418671849183/ viewed on 27-04-2016

Figure no 7a : https://c2.staticflickr.com/6/5018/5397257619_5baaoe1o1c_b.jpg viewed on 15-6-2016

Figure no $7 \mathrm{~b}$ :

https://www.lempertz.com/uploads/tx_lempertzproject/Lempertz_1053_507_Asian_Art_A_bronze_fig ure_of_Khando.jpg 29-6- 2016

Figure no 8 : https://s-media-cache-ako.pinimg.com/236x/1e/fi/8d/1efi8d51f6b9672fbb7d8fa2df2535a4.jpg viewed on 24-06-2016

Figure no 9: http://www.sriarts.com/ritual/Prabhavalli4oo.jpg viewed on 15 - 6 - 2016

Figure no $10:$ http://krscrafts.com/images/brass-bronze/BRASS\%2oTHIRUVACHI\%202.jpg

viewed on $15-6$ - 2016

Figure no 11 : http://3.imimg.com/data3/KP/JC/MY-9632764/kumaran-50ox50o.jpg

viewed on $15-6$ - 2016

Figure no 12: http://www.indiamart.com/abharan-jewellers-bengaluru/silver-temple-artefacts.html viewed on $11-6-2016$

Figure no 13: Illustrated by the author Prasanna E. Khamitkar 
Figure no 14: Illustrated by the author Prasanna E. Khamitkar

Figure no 15: Illustrated by the author Prasanna E. Khamitkar

Figure no 16 https://bronzesofindia.com/lakshmi-narayana/ viewed on 14 - 6 - 2016

Figure no 17 http://www.indianbronzes.com/view-piece/533-umamaheshvara-ibh135 viewed on 28 -042016

Figure no 18 http://www.metmuseum.org/toah/works-of-art/2008.271/ Viewed on 6-5- 2016

Figure no 19 http://www.michaelbackmanltd.com/175.html viewed on 27-04-2016

Figure no 20 https://s-media-cache-

ako.pinimg.com/236x/02/4c/17/024c172cfd8b8o49cf8f2bd666c173a5.jpg viewed on 14-6- 2016

Figure no 21 http://www.lotussculpture.com/mm5/graphics/ooooooo1/1-seated-bronze-ganesha.jpg viewed on $14^{-}-6-2016$

Figure no 22 http://collections.vam.ac.uk/item/O72386/vishnu-and-his-consort-supported-figureunknown/ 30-6- 2016

\section{Acknowledgement:}

The author acknowledges the contribution of Dr. Shreekant Pradhan, Deccan College, Pune for his valuable insight.

Dr. Manjiri Bhalerao and Dr Sanjay Eksambekar for their vision.

The author also acknowledges museums and the sites from where the images have been downloaded :

The Metropolitan Museum of Art, New York, http://www.metmuseum.org/

The National Museum, New Delhi, http://www.nationalmuseumindia.gov.in/

Ashutosh Museum Calcutta, http://www.caluniv.ac.in/museum/museum.html

Chazen Museum of Art, Madison, Wisconsin, United States

Pintrest, https://in.pinterest.com/

Flicker , https://www.flickr.com/

Sriarts, http://www.sriarts.com/

London,Victoria and Albert Museum : http://collections.vam.ac.uk/item/O72386/vishnu-and-his-consortsupported-figure-unknown/

KRS Crafts - Exporter of complete Indian handicrafts articles, http://krscrafts.com

Abharan Jewellers, http://www.indiamart.com/proddetail/prabhavali-s12-silver-temple-artefacts6676223488.html

Bronzes of India, https://bronzesofindia.com

Indian Bronzes, http://www.indianbronzes.com

Lotus Sculpture, http://www.lotussculpture.com, Kyle tortora, Founder Lotus Sculpture 